\title{
КОНСТИТУЦІЙНО-ПРАВОВИЙ СТАТУС ВИЩОЇ РАДИ ПРАВОСУДДЯ: МЕТОДОЛОГІЧНІ ПІДХОДИ ДО ЙОГО ДОСЛІДЖЕННЯ
}

Халюк С. О.

Методологія дослідження конституційно-правового статусу Вищої ради правосуддя України має доволі складну та неоднозначну структуру, яка, на нашу думку, не обмежена лише сукупністю філософських, загальнонаукових чи спечіально-наукових методів. У цій cmammi розглянуто методологічну основу дослідження конституційно-правового статусу Вищої ради правосуддя України. Зокрема, були визначені методологічні підходи до такого дослідження. У науковій статmі були проаналізовані наукові позиції таких авторів, як Ю.М. Бисага, С.В. Бобровник, Л.М. Дешко, В.М. Кампо, М.С. Кельман, М.І. Козюбра, М.В. Костицький, П.М. Рабінович, О.Ф. Скакун, Т.І. Тарахонич та інші.

Методологія дослідження конституційно-правового статусу Вищої ради правосуддя України має доволі складну та неоднозначну структуру, яка не обмежена лише сукупністю філософських чи загальнонаукових методів. Дослідження категорії «статус» nотребує системного підходу, що сприяє досягненню максимального ступеню об'єктивності за умови чітко визначеного методологічного інструментарію. Отже, у статmі проаналізовано ключові концептуальні підходи до розуміння складових структурних елементів методології як філософсько-правових категоріŭ.

Відзначається, що єдиних науково обгрунтованих методологічних підходів наукового дослідження конституційно-правового статусу Вищої ради правосуддя, його сутності та функціонального призначення не вироблено. А тому існує необхідність наукового узагальнення існуючих поглядів учених та уточнення функціональних можливостей методологічних підходів наукового пізнання розглядуваHOго cmamycy.

Відповідно до розглянутих наукових позицій запропоновано авторську методологічну основу для дослідження конституційно-правового статусу Вищої ради правосуддя в Україні, що може стати підгрунтям для подальших наукових розвідок у цьому напрямі.

Ключові слова: методологія, методологічний підхід, конституційно-правовий статус, Вища рада правосуддя.
Khaliuk S. O. Constitutional and legal status of the High Council of Justice: methodological approaches to its study

The methodology for studying the constitutional and legal status of the High Council of Justice of Ukraine has a rather complex and ambiguous structure, which, in our view, is not limited to a set of philosophical, general or special scientific methods. This scientific article considers the methodological basis of the study of the constitutional and legal status of the High Council of Justice of Ukraine. In particular, the methodological approaches of such a study were identified. The scientific article analyzed the scientific positions of such authors as Yu.M. Bisaga, S.W. Бобровник, L.M. Deshko, V.M. Campo, M.S. Kelman, M.I. Kozyubra, M.V. Kostytsky, P.M. Rabinovich, O.F. Skakun, T.I. Tarakhonych and others.

The methodology for studying the constitutional and legal status of the High Council of Justice of Ukraine has a rather complex structure, which is not limited to a set of philosophical or general scientific methods. The study of the category "status" requires a systematic approach that helps to achieve the maximum degree of objectivity in terms of clearly defined methodological tools. Therefore, the article analyzes the key conceptual approaches to understanding the constituent structural elements of methodology as a philosophical and legal category. It is noted that the only scientifically sound methodological approaches to the scientific study of the constitutional and legal status of the High Council of Justice, its essence and functional purpose have not been developed.

In accordance with the considered scientific positions, the author's methodological basis for studying the constitutional and legal status of the High Council of Justice in Ukraine is proposed, which can become a basis for further scientific research in this direction.

Key words: methodology, methodological approach, constitutional and legal status, High Council of Justice.

Постановка проблеми. Актуальність теми дослідження зумовлена тим, що сучасна держава постає складним структурованим багатовимірним феноменом. А тому до структурних складників

() Халюк С. О., 2020 
такої держави можна віднести в тому числі органи державної влади. Визначивши предметом дослідження конституційно-правовий статус Вищої ради правосуддя, зауважимо на тому, що передумовою ефективності такого дослідження $\epsilon$ методологічна основа пізнання цього правового явища. Адже у сучасній українській правовій науці відбувається процес докорінного переосмислення традиційних засобів пізнання як елементів змісту методології та водночас актуалізується пошук нових, що сприяє розширенню їі інструментальних можливостей. Окремо наголошується на необхідності теоретичного осмислення пізнавальної ролі раціональних та ірраціональних засобів пізнання, використання яких суттєво доповнює змістовну характеристику методології. Це знаходить відображення в подоланні вузьконормативного підходу до осмислення правової реальності [7, с. 35].

Стан дослідження. Серед українських науковців, які розглядали питання методологічних основ пізнання, необхідно назвати В.Б. Авер'янова, В.В. Дудченко, М.І. Козюбру, А.М. Колодія, В.В. Копейчикова, Н.М.Крестовську, В.В.Лемака, О.М.Лощихіна, Н.М. Оніщенко, П.М. Рабіновича, О.Ф. Скакун, М.В. Цвіка та інших.

Метою статті $\epsilon$ потреба в аналізі наукових поглядів авторів щодо методологічних підходів та виокремлення серед них тих, які фактично забезпечать дослідження конституційно-правового статусу Вищої ради правосуддя України.

Виклад основного матеріалу. Реформування Вищої ради правосуддя відбулося синхронно з відповідними змінами, які торкнулися судової системи України загалом. Навіть більше, можна стверджувати, що таке реформування $\epsilon$ одним 3 елементів всієї системи трансформації судової влади в Україні, яка в даний момент активно реалізовується. Правовий статус Вищої ради правосуддя зазнав суттєвих змін у зв'язку із реалізацією конституційної реформи 2015-2016 років, яка зумовлена потребою у функціонуванні незалежного професійного органу, завданнями якого було б здійснення добору суддівського корпусу, притягнення їх до відповідальності, встановлення етичних правил суддівської професії, а також окремі повноваження щодо прокурорів. У світовій конституційній практиці статус подібних до Вищої ради правосуддя органів визначається по-різному, що своєю чергою спричинило наукову дискусію стосовно правового статусу Ради правосуддя в Україні. А відтак потрібно констатувати, що питання статусу Вищої ради правосуддя в Україні $\epsilon$ достатньо дискусійним. Тож проблема відсут- ності чіткого розуміння конституційно-правового статусу Вищої ради правосуддя $є$ достатньо наочною.

Значна кількість складових елементів, які утворюють таке поняття, як «конституційно-правовий статус Вищої ради правосуддя», очікувано передбачає наявність різноманітних підходів щодо їх дослідження. Як наслідок - необхідність у використанні різних методів, прийомів, підходів, які необхідні для проведення дослідження. При цьому абсолютно зрозуміло, що вибір цих інструментів, які необхідні для реалізації дослідження, зумовлюється поставленою метою, визначеним предметом, сформульованими завданнями, а також характером наявного матеріалу обраного дослідження. А тому сукупність обраних методів, підходів, прийомів утворює відповідно упорядковану систему, що визначає у заданій послідовності їх використання з теоретичними та емпіричними матеріалами. Таким чином, методологічний аспект дослідження конституційно-правового статусу Вищої ради правосуддя $є$ визначальним. При цьому, як зазначає В.М. Кампо, методологія наукового дослідження базується на використанні принципу плюралізму у виборі методологічних підходів, методів і прийомів. Адже саме методологічний плюралізм і конкуренція наукових ідей $\epsilon$ ознакою того, що представники різних доктрин виявляють свободу наукової творчості, а це - найперша запорука успішності та конкурентоздатності [1, с. 163].

Отже, в процесі наукового пізнання важливе місце в методології наукового дослідження відводиться методологічним підходам. Як зазначає T.І. Тарахонич, філософсько-світоглядні підходи формують наукову позицію дослідника, забезпечують ґрунтовну оцінку відповідних явищ та процесів, спрямованість дослідження на отримання певного результату. На думку автора, який досліджував проблему правового регулювання та правового впливу, основні пізнавальні категорії філософії права, такі як конкретне і абстрактне, явище та сутність, зміст та форма, структура та елементи, окреме та загальне тощо, дають змогу всебічно охарактеризувати правове регулювання та правовий вплив і дійти науково обґрунтованих висновків щодо розуміння їх змісту та сутності [2, с. 17].

У найбільш загальному вигляді поняття підходу тлумачиться як «сукупність способів, прийомів розгляду чого-небудь, впливу на кого-небудь чи що-небудь, ставлення до кого-небудь або чого-небудь» [3, с. 785]. Науковці-правники 
висловлюють власне бачення щодо даної категорії. Зокрема, С.В. Бобровник зазначає, що методологічний підхід - це сукупність знань про процес наукового дослідження [4, с. 111]. На думку Н.Н. Тарасова, «методологічний підхід у правознавстві - це те, як право та правові явища можуть бути усвідомлені в процесі дослідження» [5, с. 47]. Своєю чергою П.М. Рабінович вказує на те, що концептуальним підходом можна вважати побудовану на гранично загальних (філософських) категоріях світоглядну аксіоматичну ідею (засаду), яка постулює загальну стратегію дослідження, відбір досліджуваних фактів та інтерпретацію результатів дослідження [6, с. 24].

Своєю чергою М.С. Кельман надав своє розгорнуте бачення щодо проблеми розуміння методологічних підходів. На його думку, зважаючи на гомогенність структури підходу та основ науки, які мають три взаємозалежні рівні (світоглядний, теоретичний, інструментальний або методичний), запропоновано визначати підхід як комплексний алгоритм осмислення дійсності, що виникає у результаті поєднання «фундаментальних ідей» і певних методів, тобто як специфічну єдність світоглядного, теоретичного і методичного знання, у якій головним є визначений суб'єктом пізнання порядок поєднання теорії та методу. Пізнавальна цінність «підходу» пояснюється тим, що в межах його змісту: а) «віддзеркалюється» емпіричний базис науки; б) поліморфізм теоретичного знання зводиться до «фундаментальних ідей» та базисних онтологічних постулатів, за допомогою системного поєднання яких формуються цілісні уявлення про «наукову картину правової реальності»; в) розмаїтість існуючих методів, методик дослідження зводиться до сукупності найбільш істотних та іманентних предмету пізнання з виключенням суто технічних засобів і процедур обробки наукової інформації; г) визначаються вихідні філософські та світоглядні принципи, що забезпечують цілісність підходу та його функціональність як специфічного способу пізнання права [7, с. 37].

У широкому розумінні методологічний підхід $\epsilon$ системою принципів та методів пізнання як філософських, так і конкретно наукових, що ґрунтуються на певних теоретичних положеннях, концепціях, парадигмах. Важливою особливістю методологічного підходу є спрямованість на отримання результату, що може мати практичне застосування. Для дослідження будь-якого об'єкту можна використати декілька методологічних підходів залежно від цілей і завдань, доступності методів і методик [8, с. 20].
При цьому деякі автори наголошують на пошуку міждисциплінарних підходів та інтеграції різних напрямів. Як зазначає Ю.В. Цуркан-Сайфуліна: «Одна з особливостей сучасної юридичної науки - іï спрямованість на пошук міждисциплінарних підходів до розкриття різних аспектів правового життя. Міждисциплінарність сьогодні стає головною формою становлення нового знання, оскільки вважається, що повноцінна нова наукова гіпотеза не може виникнути «всередині» наявного знання, а тому наукову новизну забезпечує метафоричне перенесення знань з однієї сфери в іншу» [9, с. 262]. Водночас таку тезу уточнюють Ю.М. Бисага та Л.М. Дешко, які зазначають, що методологія дослідження має бути побудована не на трансдисциплінарному підході, а саме на міждисциплінарному підході, оскільки 1) ці дисципліни мають бути сумірними системами знання; 2) він дає змогу поєднати в одну систему дослідницькі завдання окремих дисциплін, які $\epsilon$ сумірними системами знання [10, с. 21].

В той же час Р.Г. Ботвінов зауважує на тому, що саме в інтеграції (раціональному об'єднанні, синергії) різних напрямів у вивченні державно-правових явищ, різноманітності методологічних підходів і прийомів, їх взаємодоповненні слід здійснювати методологічні побудови при дослідженні проблем держави [11, с. 46].

Звернувшись до методологічних підходів, можемо відзначити значну їх кількість. Зокрема, П.М. Рабінович відносить до таких підходів діалектичний, метафізичний, матеріалістичний, ідеалістичний, гностичний, агностичний, антропологічний, потребовий, персоналістичний (людиномірний), комунітарний (колективістський), комунікативний, герменевтичний, сінергетичний [6, с. 24]. Також можна відзначити точку зору Г.Я. Пришляк, яка виокремлює такі методологічні підходи, як детермінаційний, діалектичний, екзистенціалізм, персоналізм, біхевіоризм, історизм, нормативізм, синергетизм, соціологічна школа, психологічна школа [12, с. 37].

Достатньо переконливо виглядає точка зору М.В. Костицького, який запропонував поєднати історичний і конкретно-соцілологічний підходи. На думку науковця, це проявляється у тому, що дослідження особливостей державно-правових явищ на сучасному етапі можна здійснювати шляхом зіставлення з аналогічними державно-правовими явищами, які мали місце у минулому. Також, з позиції вченого, варто поєднати історичний та аксіологічний підходи, адже це дало б можливість детальніше проаналізувати історично 
усталені в українському державотворенні і правотворенні основні цінності та принципи, які мали б бути обов' язково враховані у реформуванні сучасної системи державних органів та системи права [13, с. 16].

Узагальнено можна констатувати, що у сучасних правових дослідженнях найбільш широко використовуються аксіологічний, антропологічний, історичний, компаративний, структурнофункціональний, комунікативний і цивілізаційний підходи. Саме вони найчастіше визначають парадигму інтелектуального осягнення права та $є$ базовими для сучасної юриспруденції.

На наше переконання, зважаючи на предмет дослідження, характеризуючи підходи до вивчення конституційно-правового статусу Вищої ради правосуддя, варто виокремити такі методологічні підходи: антропологічний підхід, системний підхід, аксіологічний, історичний підхід, функціональний підхід, порівняльний підхід. Розглянемо більш детально методологічні підходи, які можуть бути застосовані до наукового пізнання конституційно-правового статусу Вищої ради правосуддя.

Насамперед, характеризуючи методологічні підходи з метою дослідження правового статусу Вищої ради правосуддя, видається важливим розглянути антропологічний підхід. Адже для будь-якої сучасної цивілізованої демократичної держави основною соціальною цінністю $\epsilon$ людина, іiі життя, здоров'я, честь і гідність, права й свободи, а також можливість їх реалізації та забезпечення. Сьогодні в демократичних державах підвищується значущість гарантування прав громадян, зокрема інституційних. О.Ф. Скакун вважає, що антропологічний підхід $є$ ключовим до всіх державно-правових явищ, «відповідно до якого людина як біосоціальний індивід $\epsilon$ «мірою всіх речей», у тому числі державно-правових явищ. Такий підхід ставить людину в центр правової реальності і вивчає їі роль у створенні цієї реальності, життєдіяльність усередині неї, взаємний вплив (включаючи деструктивний) людини і правової реальності» [14, с. 29]. А тому, узагальнюючи позиції науковців, зауважимо на виключній важливості застосування антропологічного підходу у власних дослідженнях. Адже саме держава повинна створити належні умови, які забезпечать реалізацію прав і свобод особи та сприяти відновленню порушених прав. Що може відбуватись в тому числі шляхом формування системи органів судової влади із залученням Вищої ради правосуддя.
Наступним методологічним підходом є системний. Під системним підходом у широкому сенсі розуміють метод дослідження, за якого об'єкти дослідження розглядаються як частини та елементи певного цілісного утворення. Ці частини та елементи, взаємодіючи між собою, формують нові якості цілісного утворення (системи), відсутні у кожного з них окремо. Поняття «елемент» розуміється як мінімальний, вже неподільний компонент в рамках даної системи. Зв'язок між елементами системи більш стійкий, впорядкований та внутрішньо необхідний, ніж зв'язок кожного з елементів з навколишнім середовищем. Використання даного методологічного підходу надає можливість дослідити місце та роль Вищої ради правосуддя в системі державного апарату та встановити ії функціональне призначення в національній системі правосуддя.

Характеризуючи конституційно-правовий статус Вищої ради правосуддя, важливо спиратись також на аксіологічний підхід. Адже взаємовідносини держави й особи залежать насамперед від ціннісного складника, на якому ці відносини формуються. Вища рада правосуддя як орган суддівського врядування покликана забезпечити незалежність судової влади, іiі функціонування на засадах відповідальності, підзвітності перед суспільством, формування доброчесного та високопрофесійного корпусу суддів, додержання норм Конституції і законів України, а також професійної етики в діяльності суддів і прокурорів. Безперечно, що базовими передумовами вказаної діяльності $\epsilon$ система соціальних цінностей, які притаманні демократичним державам: народовладдя, верховенство права, законність, рівність усіх громадян перед законом і судом, компетентність, відповідальність тощо.

Історичний підхід полягає у необхідності вирішення проблеми пізнавального оволодіння тим чи іншим явищем у певній ретроспективі. Завдяки історичному підходу стає можливим оцінити як те чи інше явище виникло, які етапи у своєму розвитку пройшло, в тому числі з огляду на його зміст нині. Проте необхідною $\epsilon$ й оцінка минулого з позиції сучасності, адже дійсну оцінку тих чи інших явищ можна дати лише за такої умови. Тому під час дослідження статусу Вищої ради правосуддя мають бути проаналізовані передумови та фактори, які визначили в кінцевому рахунку сучасний статус даного органу.

Ще одним важливим методологічним підходом $\epsilon$ функціональний, адже держава як певна система та органи, що іiі утворюють, мають функціональний характер. Структурні елементи 
будь-якої системи визначаються її функціями. В той же час, коли ми говоримо про дослідження статусу Вищої ради правосуддя, використання даного підходу дає можливість поглибити уявлення щодо соціального призначення сучасної держави загалом і Ради правосуддя зокрема. Також завдяки функціональному підходу можемо говорити про удосконалення статусу даного органу в парадигмі «компетенція-структура-результат».

У сучасних умовах глобалізації та інтеграції особливого значення набуває порівняльний підхід. Компаративісти у своїх дослідженнях здійснюють порівняння різноманітних аспектів існування держави, її елементів, інститутів. На думку таких компаративістів, як К. Цвайгерт і Х. Кьотц, порівняльний підхід діє найбільш ефективно, коли дослідник, по-перше, викладає найбільш суттєві дані щодо національної держави окремо; по-друге, використовує їх як основу для поглибленого критичного аналізу; по-третє, пропонує свої висновки, що мають значення для аналізу власної національної держави. [15, с. 19]. А тому, на наш погляд, за умов розвитку європейської інтеграції України з країнами Європейського Союзу порівняльний підхід може сприяти гармонізації міжнародного, європейського та національного права в частині адекватного запозичення розроблених міжнародних стандартів та правових норм, які ефективно діють в окремих зарубіжних країнах і визначають статус органів, відповідних Вищій раді правосуддя України.

Висновки. Саме комплекс обраних методологічних підходів надасть можливість системно дослідити конституційно-правовий статус Вищої ради правосуддя, здійснити порівняльно-правову характеристику статусу відповідних органів у зарубіжних країнах та надати на цій підставі висновки та пропозиції, які б максимально чітко відображали вимоги сучасних тенденцій реалізації судової реформи загалом. Хоча при цьому ми свідомі того, що набір визначених нами світоглядних методологічних підходів не $\epsilon$ сталим і може мати тенденцію до збільшення по мірі вирішення поставлених дослідником завдань. А тому будь-який перелік не може вважатись вичерпним.

\section{Література}

1. Кампо В.М. Методологія досліджень конституційної юстиції в Україні: науковий огляд. Право України. 2014. № 6. С. 158-170.

2. Тарахонич Т.І. Методологічні підходи та принципи дослідження правового регулювання. Часопис Київського університету права. 2009. № 3. С. 15-19.
3. Великий тлумачний словник сучасної української мови / уклад. і голов. ред. В.У. Бусел. Київ; 2004. 1035 c.

4. Бобровник С.В. Компроміс і конфлікт: методологічні підходи до дослідження. Правова держава. 2009. Вип. 20. С. 110-117.

5. Тарасов Н.Н. Метод и методологический подход в правоведении (попытка проблемного анализа). Правоведение. 2001. № 1. С. 31-50.

6. Рабінович П.М. Наука філософії права: до характеристики предмета й методології. Проблеми філософії права. 2003. Т. 1. С. 22-26.

7. Кельман М.С. Методологія сучасного правознавства: становлення та основні напрями розвитку. Психологія і суспільство. 2015. № 4. С. 33-46.

8. Олійник Я., Кононенко О., Мельничук А. Методологічні підходи до вивчення формування та розвитку регіональних систем природокористування. Вісник Київського національного університету імені Тараса Шевченка. 2012. № 60. С. 20-24.

9. Цуркан-Сайфуліна Ю.В. Міждисциплінарна методологія в контексті права і влади. Підприємництво, господарство і правом. 2017. № 11 (261). C. 262-267.

10. Бисага Ю.М., Дешко Л.М. Міждисциплінарність як умова розв'язання комплексної проблеми щодо конституційного права кожного звертатися до міжнародних судових установ та міжнародних організацій. Науковий вісник “Актуальні проблеми вітчизняної юриспруденції. 2016. №4. С. 18-21.

11. Ботвінов Р.Г. Методологія дослідження публічної служби особливого призначення. Аспекти публічного управління. 2017. № 12. Том 5. С. 42-49.

12. Пришляк Г.Я. Методологія дослідження демократичного контролю в Україні. Економіка. Фінанси. Право. 2013. № 1. С. 35-37.

13. Костицький М.В. Ключові підходи до методології пізнання української історико-правової дійсності. Науково-інформаційний вісник “Право”. 2015. № 12. С. 12-17.

14. Скакун О.Ф. Теорія держави і права (Енциклопедичний курс) : підручник. Харків : Еспада, 2006. $776 \mathrm{c}$.

15. Цвайгерт К., Кетц Х. Введение в сравнительное правоведение в сфере частного права : в 2 т. Москва : Международные отношения, 2000. Т. 1. $480 \mathrm{c}$.

Халюк С. O., кандидат юридичних наук, доцент, доцент кафедри конституційного права та прав людини Національної академії внутрішніх справ 